\title{
The Arlanda Airport Rail Link: Lessons Learned from a Swedish
}

\section{Construction Project}

\author{
JAN-ERIC NILSSON * \\ Swedish National Road and Transport Research Institute (VTI) \\ LARS HULTKRANTZ \\ Swedish National Road and Transport Research Institute (VTI) and Örebro University \\ URBAN KARLSTRÖM \\ Swedish National Road and Transport Research Institute (VTI)
}

\begin{abstract}
The Stockholm - Arlanda airport rail link is a public-private partnership opened for traffic in 1999. This paper addresses costs and benefits of giving a private company control over one section of the otherwise public railway network. The project has reduced the pressure on the public sector's budget and reduced the need to raise efficiency distorting tax revenue. The number of passengers has been below expectations. Track capacity may, however, be sufficient to negotiate an increase the supply of rail services by way of extending existing commuter trains, in that way attracting more passengers.
\end{abstract}

\section{Introduction}

Sweden and the United Kingdom launched several regulatory reforms of previous public monopoly industries in the 1980s and early 1990s. For instance, British Telecom (BT) was

\footnotetext{
* Contact author. VTI, Box 55685, 10215 Stockholm, Sweden. E-mail: jan-eric.nilsson@vti.se The authors have had the following previous involvement in the Arlanda link project: Nilsson was part of a 1986 committee that first suggested having the project built and was subsequently employed at Banverket when the project was made part of its 10-year investment program. Karlström was director of policy planning at the Ministry of Transport and Communication between 1991 and 1994 and part of the project procurement process. In year 2000, Hultkrantz made an assessment to the Parliament's Audit of the background material for starting the project. Hultkrantz and Nilsson have co-authored an ex post assessment of the investment for National Audit (Enberg, Hultkrantz and Nilsson 2004). The present paper is based on the latter report and also the subsequent audit report (Riksrevisionen 2004); no further references to background sources are given except for when additional material compared to these two reports has been used. We are grateful for research assistance from Nils Enberg and for comments on previous versions of the paper from persons involved in different states of the process. All remaining errors are our responsibility.
} 
privatized and the Swedish Railways (SJ) was vertically separated, changes which both became role models for pro-competitive reforms that followed in other European Union countries. The subsequent industrial reforms involved a broad range of measures, including new legislation, structural break-up of the monopoly, change of ownership and gradual opening for market entry.

Much of the economic literature on these reforms addresses regulatory issues and the development of remedies against abuse of monopoly power, including price caps and forward-looking cost-based prices (Laffont \& Tirole (1993) summarizes the core of "the new regulatory economics"). However, the government's role in reforms within the railway sector extends beyond that of being legislator and regulator, in that it - at least immediately after a vertical separation - owns both infrastructure and an incumbent operator. This makes it necessary to have a premeditated position with respect to investment in and funding of infrastructure projects and a clear view of its sector policy on competition.

With Sweden going for vertical separation of its railways, the rail link to Arlanda airport outside Stockholm is an odd element. First, the airport rail link is a finance-buildtransfer-operate contract between the government and a private consortium. Contracting with a private party in order to provide for (partial) off budget funding of infrastructure was (and still is) not commonplace. Secondly, and in contrast with the industry at large, the private partner both runs railway services and has some control over access to the infrastructure. In a sense, the contract therefore reintroduces a degree of vertical integration.

Arlanda airport is situated between Stockholm City and Uppsala, where a $75 \mathrm{~km}$ double-track line since long connects the cities. The old line is at a distance of about $3 \mathrm{~km}$ from the airport. Public transport between Stockholm and the airport (42 km) was and still is provided by a bus shuttle. A qualification for the Arlanda project was that track capacity on section A in Figure 1 below was constrained. To make it feasible to operate a dedicated Arlanda service, it was therefore necessary to build bring forward the construction of another two tracks.

The section linking the airport to the original tracks from the south, including three stations beneath the airport (section B), is the core of the Arlanda project. A third component is "the northern bend", linking Arlanda to the main line also to the north (section C).

This paper describes some aspects of the process that lead to the 1994 decision to initiate the project, as well as the contracts that regulate the respective duties of state and private company, and it also summarizes some experiences from a year 2006 perspective. The prime purpose is to highlight essential tradeoffs present in public private partnerships from the specific process that has resulted in a high-standard rail shuttle between Arlanda airport and downtown Stockholm. We also comment on the appropriateness of creating facility-based competition within a railroad industry that is otherwise vertically separated.

The paper proceeds with a presentation of the deliberations made before the contract was signed (section 2) where after an ex post assessment of the project is given (section 3). Section 4 considers the Arlanda project from the perspective of railway sector organization; section 5 concludes. 


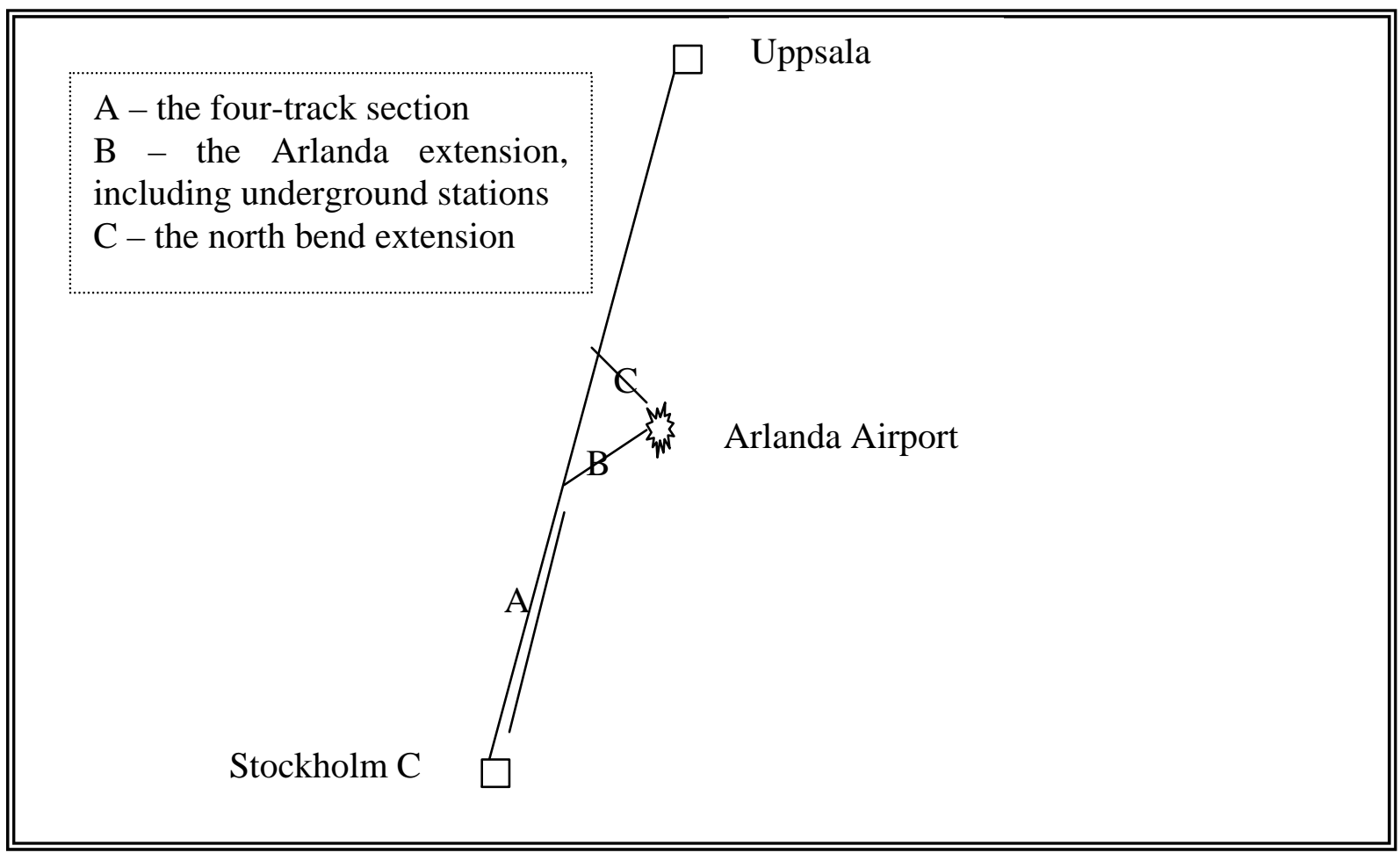

Figure 1: The prime components of the Arlanda airport rail link.

\section{Ex ante considerations}

We discuss considerations behind the signing of the PPP contract under three separate headlines; the process itself (2.1), the political prerequisites for the project (2.2) and the content of the contract (2.3).

\subsection{The process}

A first formal proposal for a railway link to Arlanda airport was made in a 1986 committee report. A couple of years later, the railway industry was being vertically separated. One consequence was that, in the same way as for roads, investment in railway infrastructure came to be paid for by government appropriations. A 10-year investment program established in 1989 by the infrastructure holder, the National Railway Administration (Banverket), subsequently gave the Arlanda project top priority.

The then social democratic government responded by asking Banverket to assess the possibility to have the project built and financed by the private sector. The agency's estimate was, however, that future revenue from ticket sale would not be sufficient to recover costs for both operations and infrastructure investment. The 1991-1994 nonsocialist government still wanted to have the project built and at least partially financed by the private sector. ${ }^{1}$ For this reason, it established a working group within the ministry, chaired by a retired business CEO and manned by officials that had been working with

\footnotetext{
${ }^{1}$ After having held majority since 1982, social democrats were ousted in the 1991 election. The non-socialist majority lasted for three years, social democrats making a comeback in the fall 1994 election.
} 
complex contracting projects and also with a political representation; neither the incumbent operator, SJ, nor Banverket were seconded. An international investment bank was hired to provide advice.

The procurement process sought to induce bidders from the international arena to enter the contest. The composition of the working group in combination with active marketing signaled the government's commitment to a transparent and open process. The government moreover, gave the working group an wide mandate and committed itself not to get involved in the choice of winning consortium or the details of the deal to be negotiated other than in one respect: To say yes or no to the working group's final proposal for solution. ${ }^{2}$

In early 1993, riksdagen (the Parliament) decided to have the four-track and the northern bend sections (that is, A and $C$ in Figure 1) built and paid for over the government's budget. A pre-qualification round saw about 30 firms submitting bids for all or parts of the core project (that is, B). The final round comprised four bidding consortia formed after an initiative from the working group. In April 1994, the government submitted its Bill concerning basic contracting principles to riksdagen. (prop. 1993/94:213, Godkännande av grundläggande principer för avtal rörande Arlandabanan). The working group continued its deliberations with the bidders during spring and in June riksdagen approved the Bill. ${ }^{3}$

The Arlanda Link Consortium was announced to be preferred bidder in July and the contract was signed in August, one month before the election. The private consortium subsequently established itself as A-Train. It comprised NCC and SIAB, domestic construction companies undertaking all construction works and a subsidiary of Vattenfall, Sweden's leading electricity utility. A fourth owner was GEC Alstom, an European railway equipment supplier that subsequently built the trains, and the fifth was John Mowlem, a British construction company with experience in railway construction, supplying tracks, switches, signaling and telecom systems. Neither owner had any experiences from operating railway services.

A-Banan Project AB, in the sequel referred to as A-Banan, was established to act as the government's agent, and most contracts etc. were administrated through this company. ABanan is owned by Banverket and Luftfartsverket (the Swedish Civil Aviation Administration, subsequently referred to as the airports agency). In this way, the intention was to use the agencies to nurse and develop the relationship with the contractor as time and traffic develops. Train services were opened in November 1999 which was one year ahead of the schedule established in the Act.

\footnotetext{
${ }^{2}$ It turned out that the pressure on the group to award the contract to a domestic bidder became fierce. The government did not, however, budge from its commitment. Cf. the US Congress giving "fast track authority" to the government in trade negotiations, interpreted from the perspective of transaction cost economics in Dixit (1996), in particular section 2.3.

${ }^{3}$ A recent audit report made an ex post assessment of whether the parliament's 1994 decision had actually been implemented: Does the government and its agencies operate according to this decision and has the parliament been adequately informed about the outcome after that this decision was made? The auditors expressed concerns with respect to poor feedback information and in particular with respect to that the government's representative organization, A-Banan, had been given poor instructions. Cf. Riksrevisionen (2004).
} 


\subsection{The political considerations}

One aspect of the political process to establish a train service to Arlanda was the airport agency's plans to have a third runway built. The runway construction permit was conditioned on that $\mathrm{NO}_{\mathrm{x}}$ and $\mathrm{CO}_{2}$ emissions from the airport and its surroundings should not exceed 1990 levels, and the train was seen to be an important tool to meet this target. The emission cap provides the airport agency with an interest in curbing the growth of bus and car traffic to the airport in order to provide scope for growth in air travel.

Another political objective was to open up for private sector participation in the financing of what is otherwise handled as a public sector responsibility. The growing demand for public money at large, in combination with a severe budget crisis in the early years of the decade, made most political parties interested in off-budget funding mechanisms. The non-socialist government of the day also saw the entry of a private contractor as a means to simplify entry into a (future) deregulated national railway market. It also saw entry as a means for stimulating the testing of innovative infrastructure design and new ways to operate the services.

The parliament's 1994 decision to have the project built also made explicit reference to its economic rationale, established in Banverket's early Cost-Benefit Analysis. The benefits - time savings, ticket revenue, lower emissions and reduced congestion from cars and busses due to a switch of mode etc. - exceeded its costs, even if ticket revenue was not expected to be sufficient to recover investment costs.

In order to integrate the airport link with the national railway grid, the parliament also wanted to have section $\mathrm{C}$ built in spite of its poor commercial value. It therefore had to foot the bill for this component of the project.

\subsection{The contract}

The Arlanda link investment is a finance-build-transfer-operate agreement between Sweden's government and a private consortium. The private partner built sections B and C and paid for (parts of) the investment costs but A-Banan was made owner of the infrastructure from that construction was concluded. A-Train is, however, entitled to run passenger trains for a 45-year period, with an option for a 10-year extension. After that, the control over infrastructure is to be handed over to the government

The contract was based on minimum technical requirements established by A-Banan but construction choices were otherwise controlled by the operator. A-Train could therefore design links B and C to optimize the project's lifetime costs according to its own interests, and it also decided which rolling stock to acquire. The cost consequences of new ordinances or laws with direct bearing on the project, or unforeseen archaeological excavations would be paid for by the government. In all other respects, the consortium had to account for construction cost risks and unexpected increases of subsequent operation costs. Moreover, the consortium accepted the full market risk, meaning that it has to accommodate the consequences of slumps in air travel as well as incorrect travel forecasts.

The following financial arrangements were established by the June 1994 parliamentary decision. First, the state committed itself to pay for the northern bend (link C) and for at least 50 percent of the costs for connecting links $\mathrm{B}$ and $\mathrm{C}$ to the main line. Second, the consortium promised (a) to contribute with at least SEK 0,6 billion ${ }^{4}$ or 15 percent of the

\footnotetext{
${ }^{4}$ When this was written in 2007, the exchange rate it $€ 1=$ SEK 9,30 and \$1=SEK 6,75.
} 
total project cost in the form of share capital or loans, and (b) to raise at least 75 percent of total costs for link B on commercial terms.

Third, the remaining construction costs were provided by a "conditional loan" on SEK 1 billion from the government. It was obvious to the government's working group that the debt burden would be substantial during the first years of operations. On the other hand, the surplus could become substantial towards the end of the contract period when much of the debt had been paid off. The repayment was therefore deliberately skewed towards the later part of the contract's life period, after that the external loans had been paid back. Banverket pays the interest on that loan, and if all outstanding debt is repaid before the termination of the contract, Banverket shall also be compensated for this cost.

The deliberations also made it clear that there was a trade-off between the size of this loan and the degree of monopoly control delegated to the winning consortium. Restrictions on competing bus services may, for instance, have reduced the necessity to provide a loan on soft conditions substantially. Moreover, the guarantee loan has lower priority than ATrain's other debt but has higher priority than share capital that would be foregone in the event of bankruptcy. This construction of the loan aligns the interests of the government and the consortium. Recently, Spain has established Public Subordinated Participation Loans that are similar in design; see Vassallo and Soliño (forthcoming).

A fourth contractual component was A-Train's commitment to operate at least four trains per hour and direction between the airport and Stockholm city between 06.00 and 23.00. The consortium, in addition, has property rights for 6 time-slots per hour on the main line. It was also to pay for rolling stock and its maintenance as well as the maintenance costs for sections $\mathrm{B}$ and $\mathrm{C}$ of the infrastructure. A-Banan has legal control over access to the infrastructure by other users but A-Train is entitled to chare other (competing or complementary) train services on the line which it has paid for.

\section{The project five years after opening}

To contrast what has happened with ex ante expectations, we start with a comparison of projected and realized costs (3.1), also providing some further detail of the financial structure of the agreement. Section 3.2 discusses A-Train's financial result. Section 3.3 takes a look at some broader economic perspectives on the project and the scope for renegotiation of the contract is addressed in section 3.4.

\subsection{Investment costs ex ante and ex post}

Our best estimate is that total costs for sections A-C and the purchase of rolling stock in 1992 was expected to land around SEK 6 billion. Of this sum, the private consortium would be responsible for investment in section B, calculated to cost SEK 2,6 billion out of which SEK 1 billion was paid for by the guarantee loan (see table 1).

The ex ante estimates for sections $\mathrm{B}$ and $\mathrm{C}$ - the infrastructure core of the project - do not seem to be far off the actual outcome. Section A, built under Banverket's auspices, saw a cost overrun of about 25 percent. Several qualifications for these figures should however be borne in mind. First, the numbers are in different price levels but since prices were fairly stable over the period, 1992 costs have not been inflated. Low inflation is the mirror image of a sharp downturn of the business cycle. It is reasonable to expect that a depression of the sort that Sweden lived through should result in substantial cost savings 
compared with projections made for a situation with average aggregate demand relative to the construction industry's capacity.

Secondly, at least parts of the cost overrun for section A may be explained by that the ex post number includes a component for connecting the new to the existing line; we do not know if this cost was anticipated in the ex ante estimate. Third, no information about the costs for building section $C$ is available. The entry is the lump sum paid by the government to the private consortium for building section $\mathrm{C}$ simultaneously with section B.

$\begin{array}{lcc}\text { Section } & \text { Ex ante (1992) } & \text { Ex post (1999) } \\ \text { A } & 1900 & 2400 \\ \text { B } & 2600 & 2700 \\ \text { C } & 850 & 850 \\ \text { Rolling stock } & 600 & 850\end{array}$

Table 1: Ex ante and ex post costs for the Arlanda link project.

Note: Million SEK; (year of estimate).

Fourth, several different designs of the Arlanda station were considered during the planning process and the ex ante cost estimate was for a different project than the one that came to be built. It has not been possible to establish any other ex ante cost expectation and the Bill did not make any reference to a target cost. In addition, and due to commercial confidentiality, A-Train's cost fallout for building sections B and C has not been made public.

Cost overruns are endemic in public-sector projects; section A above provides one example. One reason is that projects are made more sophisticated from that the decision to initiate a project is taken to the day that the shovel is first put into the ground; another may be poor management of the construction process (Flyvbjerg et al, 2004). A-Train has never reported any cost overruns and we do not know whether costs targets were met or if escalating costs have not been made public. ${ }^{5}$

To summarize, the private partner's cost of the Arlanda contract was SEK 2,7 billion out of which SEK 1 was a government loan. The consortium borrowed another SEK 1,1 billion in banks, its share capital was SEK 400 million and in addition, its partners gave ATrain a loan of SEK 200 million. ${ }^{6}$ Except for that, rolling stock was leased on a contract costing about SEK 700 million; this contract was, however, guaranteed by the government. As of today, the government has not had to face any extra payment due to cost overruns. The deal has therefore reduced the need to raise tax revenue or sell bonds by SEK 1,7

\footnotetext{
${ }^{5}$ On the other hand, Andersson (2005) alleges that the winning consortium made a substantial profit on its engagement in the construction phase of the project.

${ }^{6}$ Riksrevisionen's (2006) audit report focuses that companies fully owned by the government were partners in the consortium. In addition, several of the loans were given by government-owned banks, adding to the risks that at the end of the day had to be borne by the public sector. One of the lenders is operating with government guarantees, providing cheaper loans than commercial banks. On the other hand, to the extent that companies owned by the government operate under commercial conditions, this could be considered to be just like any commercial financial construction. This is particularly so since any bidding consortium, at least in principle, could apply for the loans.
} 
billion in return for a project opened ahead of schedule. On top of this, the government has an (insecure) claim of SEK 1 billion from the consortium.

A conclusion that goes beyond the Arlanda link project is that the expected costs for a project in its final version should be carefully registered, in particular when a nonconventional financial construction is being implemented. If not, it is difficult ex post to assess the merits of, and problems with the financial solution used and transparency is jeopardized. On the hand, one problem with off-budget funding is that a private contractor effectively working under a fixed-price contracting regime, may not want to open the books for external review. The project's consequences for the public-sector budget may therefore be the best proxy for cost efficiency that could be made available.

\subsection{Financial aspects of the airport shuttle}

The income from an airport shuttle is the number of passengers times the unit price. The number of airport employees and, in particular, of airline travelers is therefore a crucial determinant of the project's financial prerequisites. Table 2 presents an official 1990 forecast together with the actual number of travelers passing the airport, indicating that the forecast for year 2000 (at traffic start) has overestimated the turnout. In addition, the combined consequences of an economic downturn in year 2000, the terrorist attack on September 11, 2001, the SARS epidemic etc. hit subsequent total traveling hard, in Sweden as in most countries. Another reason for the shortfall in ridership was the year 2002 crash for the IT business and the telecom industry and in particular Ericsson with much activity in Stockholm.

A non-published forecast was also made by the government's task force. In addition, each bidder made its own estimate of patronage and pricing policy before submitting a bid. Interviews indicate that the winning consortium seems to have had two starting points for their market analysis: to achieve at least the same market share as the combined train and bus shuttle between Paris and Charles De Gaulle airport; and a rule-of-thumb indicating that air traffic grows more that twice the growth in GDP, in combination with a favorable forecast for Sweden's future GDP growth.

Table 3 summarizes market shares for different modes of transport to and from the airport. Numbers should be treated with great care both since data have been collected using different methods during different years and since it covers all destinations, many of which are outside A-Train's core market. More detailed information about market shares on this core market between airport and downtown Stockholm is available but does not cover the situation before traffic start.

The table demonstrates that the train shuttle seems to have had had little effect for the market share for car and taxi, meaning that the objective to reduce road traffic has not been realized. For trips between downtown Stockholm and the airport only, market share in 2004 was around 30 percent for train (and growing) and a 17 percent for bus (slowly shrinking).

Table 4 summarizes the Arlanda shuttle's patronage. The number of passengers during the first years of service is about fifty percent of the (official) projection made for 2005. ATrain's own projection was lower but is still about 25 percent higher than outcome. Except for events outside the control of the operator, changes in the domestic market after that the contract was signed in 1995 have also had consequences for the shuttle. There are now three other airports in the greater Stockholm area that compete both for domestic and international air traffic, rather than one in the early 1990s. The motorway between Arlanda 
and downtown Stockholm has been upgraded, including a higher capacity at the airport approaches. The airport agency has also expanded affordable parking capacity which adds to its earnings and further promotes the competitive edge of private cars.

\begin{tabular}{ccccc}
\multicolumn{2}{c}{ Forecast no of passengers } & $\begin{array}{l}\text { Actual no. } \\
\text { of passengers }\end{array}$ & GDP \\
& Without train & With train & & \\
1988 & & & 10.8 & 81.7 \\
1998 & & & 16.1 & 93.4 \\
1999 & & 21.6 & 17.1 & 96.7 \\
2000 & 20.2 & & 18.3 & 100 \\
2001 & & & 18.1 & 100.4 \\
2002 & & & 16.4 & 101.6 \\
2003 & & & 15.1 & 103.5 \\
2004 & & & 16.3 & 107.0 \\
2005 & & & 17.1 & 109.1 \\
2020 & 31.5 & 33.5 & & \\
\hline
\end{tabular}

Table 2: Million airline passengers at Arlanda airport.

Note: Official 1990 forecast and outcome. Sweden’s real GDP at market prices, 2000 = 100 .

$\begin{array}{llll} & \mathbf{1 9 9 9} & \mathbf{2 0 0 1} & \mathbf{2 0 0 3} \\ \text { A-Train } & - & 19 & 19 \\ \text { Other train } & - & 4 & 5 \\ \text { Coach (Stockholm) } & 24 & 14 & 13 \\ \text { Coach (Uppsala) } & - & 2 & 2 \\ \text { Other coach } & - & 4 & 4 \\ \text { Taxi } & 23 & 22 & 21 \\ \text { Car } & 35 & 35 & 35 \\ \text { Other, no answer } & 18 & 3 & 4\end{array}$

Table 3: Market share (percent) for different modes of transport to and from Arlanda

Note: Based on interviews with departing passengers made by the airports agency.

An additional reason for the discrepancy between projections and actual patronage is A-Train's business strategy to offer short and reliant travel time for business passengers that can be charged a high price. Banverket's 1990 CBA analysis assumed a price at par with coaches and that coach services would be virtually eliminated; today's competition between train and coach is fierce.

The shuttle's high-price profile should be seen in its competitive context. Table 5 summarizes time and costs for alternative modes between downtown Stockholm and the airport. The generalized travel cost of coach and shuttle breaks even only at a very high value of time (corresponding to the upper quartile wage cost per hour of white-collar workers). The shuttle train makes no intermediate stop between origin and destination; the coach has a couple of stops while car and taxi has no limitations in this sense. From 
August 2006, a commuter train from Uppsala to the north is stopping at the airport as well as at one of Stockholm's commuter train stations. This opens up for at least some people in the greater Stockholm area to come to the airport in a non-expensive way, at least for those that have monthly or annual tickets.

The shuttle's core market is made up of people living and/or working within a northern radius of (say) three kilometers from the city centre, and also people in some of the city's southern suburbs that can connect via the public transport network; its competitive edge in other parts of the region is weak.

The consortium did not have expertise from train operations during the procurement process. It is not clear whether their investment strategy would have been different with such experts on the payroll. In particular, the trains that were supplied by one of the consortium's partners are fairly small. In order to add capacity today, a new motor unit would have to be purchased and since this particular train has not been sold elsewhere, cost per seat would be high. Moreover, capacity on the main line (section A at the map) is strained and patronage on shuttle trains is high during peak hours. Taken together, this means that it is not straightforward to start using the price to compete with coaches. In addition, the (monopoly) operator of coaches seems to be making handsome profits on the service.

\begin{tabular}{rrrrrr} 
& Passengers & Employees & \multicolumn{1}{l}{ Total } & $\begin{array}{l}\text { Official } \\
\text { forecast }\end{array}$ & $\begin{array}{l}\text { Consortium } \\
\text { forecast* }\end{array}$ \\
$\mathbf{2 0 0 0}$ & 1700000 & 400000 & 2100000 & & \\
$\mathbf{2 0 0 1}$ & 2500000 & 400000 & 2900000 & & \\
$\mathbf{2 0 0 2}$ & 2400000 & 350000 & 2750000 & & \\
$\mathbf{2 0 0 3}$ & 2200000 & 350000 & 2550000 & & \\
$\mathbf{2 0 0 4}$ & 2456000 & 365000 & 2865000 & & \\
$\mathbf{2 0 0 5}$ & 2635000 & 388000 & 3023000 & 5100000 & 4000000 \\
$\mathbf{2 0 2 0}$ & & & & 7400000 &
\end{tabular}

Table 4: No. of passengers with A-train; actual numbers and forecast in the $1994 \mathrm{Bill}$.

* Source: From SOU 1995:25, p.40

Table 6 demonstrates that A-Train's financial result has been poor but is improving. Operating costs are said to be 60 percent higher than projected by the consortium (Andersson 2005), but the big problem compared to expectations is on the revenue side. During their first years of operations, A-Train has generated revenue to cover operating while not financial costs and as a result, equity net of accumulated losses has shrunk. 2005 was the first year with a positive result. The financial costs includes interest paid on bank loans (SEK 1182 million) with a fixed interest of 6,5 percent. The SEK 370 million loan from the owner earns a rate of return of 13 percent which will, however, not be paid before the company's cash flow meets certain targets (Annual Report 2005).

The contract between A-Banan and A-Train leaves all revenue risk with an operator that has obviously been hit hard by events outside its own control. It should therefore be seen as a remarkable achievement to turn around results so soon after the collapse of the market. One consequence of the poor results during the first years of operations is that the level of share capital is now much lower than stipulated in the original consortium 
agreement. No proviso for this situation was, however, made during concession negotiations.

$\begin{array}{llllll}\text { Mode } & \begin{array}{l}\text { Time } \\ \text { (minutes) }\end{array} & \begin{array}{l}\text { Direct } \\ \text { cost/price } \\ \text { (SEK) }\end{array} & \begin{array}{l}\text { GC } \\ \text { private } \\ \text { (SEK) }\end{array} & \begin{array}{l}\text { GC } \\ \text { business }\end{array} & \begin{array}{l}\text { GC } \\ \text { high }\end{array} \\ \text { A-Train } & 20 & 200 & 224 & 269 & 290 \\ \text { Coach } & 40 & 95 & 146 & 245 & 290 \\ \text { Taxi } & 35 & 475 & 520 & 606 & 645 \\ \text { Private car } & 40 & 80 & 131 & 229 & 275 \\ \text { Commuter train } & (36+15+8=) * & (20+95+65=) * * & 257 & 404 & 472 \\ \text { (Stockholm+Uppsal } & 60 & 180 & & & \end{array}$

a)

Table 5: 2006 time, direct and generalized costs for a trip between Arlanda and downtown Stockholm.

Note: Generalized cost (GC) is calculated for private and business travelers with standard parameters (value of time 65 and 190 SEK/h, respectively). We also include reliability, valuing a standard deviation at $90 \%$ of the time value and assuming relative standard deviations at 0.1 and 0.2 of A-train and other modes, respectively. GC high is based on the upper quartile wage cost (incl. pay-roll taxes and fees) of blue-collar workers in Sweden 2005. The GC of private car does not include parking time and charges. * 36 min Stockholm Upplands Väsby, 15 min average waiting time, 8 minutes Upplands Väsby-Arlanda. ** SEK 20 Stockholm-Upplands Väsby, SEK 95 Upplands Väsby-Arlanda, SEK 65 station fee at Arlanda.

$\begin{array}{rrccc}\text { Revenue } & \text { Op. costs } & \begin{array}{c}\text { Financial } \\ \text { Costs }\end{array} & \text { Result } & \begin{array}{c}\text { Equity net of } \\ \text { accum. deficit }\end{array} \\ 341 & 305 & 86 & -50 & 105 \\ 359 & 310 & 100 & -51 & 140^{*} \\ 402 & 315 & 155 & -68 & 72 \\ 440 & 298 & 134 & 9 & 80 \\ 469 & 338 & 127 & 4 & 84\end{array}$

Table 6: Arlanda Express operating results and equity for 2002-2006, m SEK. From A-Train's Annual Reports.

* Note: SEK 85 million was added as own capital by owners in order to reduce the accumulated deficit.

In January, 2004, the Macquarie Group acquired all shares in A-Train plus its outstanding debt at a cost of SEK 400 million. Back-of-the-envelope calculations indicate that the original consortium may have made a loss of around SEK 200 million from the sale. This does not account for possible profits from the construction process itself. Macquarie invests in infrastructure and related assets in European and other OECD countries. The change of ownership means that the railway services to Arlanda airport are now operated by an owner with deep insights into the appropriate management of this sort of activity. 


\subsection{Economic aspects on the service}

One point of departure for the political ambition to raise private money for an infrastructure investment was the project's economic rationale. Banverket's 1990 analysis indicated a fairly high rate-of-return but the 1994 parliamentary decision to give the project a green light was not preceded by a new CBA. Since the project that came to be built differs from the original design, a new economic analysis that identified the pros and cons of the project after that all deliberations during the negotiation process were transformed into a final version, should have provided a basis for the government's final decision.

In particular, the initial intent was to construct a single large station in the rock under the airport, opening up several different entrances to airport terminals. The station subsequently built has two separate train tunnels. The through tunnel is used by longdistance trains, stopping at one station. A second, cul-de-sac tunnel, bends off from the main track just before getting submerged and has two stops built exclusively for the airport shuttle. Long-distance and shuttle travelers therefore do not use the same stations.

Having two tunnels and three stations rather than just one tunnel and station reduces walking distance for travelers. In addition, it may facilitate price discrimination. The standard price for a Stockholm - Uppsala ticket (cf. Figure 1) is for instance less than half that for a ticket Stockholm - Arlanda with A-Train. But a passenger who has paid SEK 200 for using A-Train is today not really aware of the fact that long-distance trains also stop at Arlanda.

A-Train's entitlement to charge other operators for using the through tunnel and station provides it with an additional source of revenue. The 1994 Bill acknowledged that this construction could be harmful for competition. To the extent that passengers and/or operators are scared off by charges above marginal costs, it is a direct loss of allocative efficiency. A-Train's right to charge for access to the station was, however, seen as a price that had to be paid for attracting private money into the project.

A-Train's franchise may be particularly damaging for potential passengers living within say 100 kilometers from the airport. For this market segment, a rail service for trips to and from the airport would require a change of trains at Stockholm central station. The extra inconvenience and the non-existence of inter ticketing in combination with the high price for the shuttle makes the car retain its competitive edge.

The Stockholm region's commuter train services have not been extended to the airport. Commuter trains would probably attract many of today's car users, in particular those that live close to the commuter train system's stations. Moreover, commuter trains would not be in direct competition with A-Train's services in view of their frequent stops and consequent longer travel time. There would probably be sufficient capacity to allow commuter trains to use the Arlanda infrastructure, as they already use the congested main line (section A).

Taken together, the 1994 decision to concession the investment to a private enterprise has not had the intended consequences for rail's market shares versus less environmentally benevolent modes of transport. There are several reasons for this: A weak market; the operator's strategy to focus on a relatively small high-price, high-quality market; fierce competition from coach and car traffic; insufficient engagement from the airport in promoting the shuttle; and a poor interest from the regional authorities to extend commuter services to the airport. 
The consequences of the new line for long-distance domestic traveling are more profound. Trains to and from regional hubs at a distance of 200 kilometers and more can now stop at Arlanda on their way to the capital. The result is that passengers on domestic flights between Stockholm and these hubs have been diverted to interregional trains with several regional airports loosing most of their departures. While this puts a heavy financial strain on these airports, it is less significant for A-Train since the number of departing long-distance passengers at Arlanda is not large enough to make any significant imprint on its revenues.

To make A-Train's service accessible for the handicapped, its platforms are higher than the national standard. Their trains could therefore not be operated on the national network, should services be deregulated, and other operators could not use A-Train's platforms.

\subsection{The future of the shuttle}

The social democrat government that resumed power about one month after that the arrangement between the government and A-Train was established in 1994, had made the project an election issue. Except for protesting against privatization of a vital part of the nation's infrastructure, a major concern was that A-Train would not have commercial reason to promote local and regional traffic. The new government promised to do its best to rip up the agreement. After the fall 1994 election, it therefore appointed a representative to try to renegotiate the deal, recommendations subsequently published in February $1995 .{ }^{7}$

In a complementary protocol, A-Train accepted to give Sweden's government the right to terminate the Arlanda agreement in year 2010 if the airport had not been "appropriately integrated" with the national railway grid at that time. The government retained the right to define what this could mean. The quo for this quid was to ascertain A-Train full compensation for the consequences of premature contract termination: The government is obliged to take over all outstanding loans as well as the contracts for leasing of rolling stock. It shall pay the value of whatever equipment A-Train may own at the date of the trade-in, it shall pay compensation for foregone return on the private consortium's risk capital as well as for its other costs.

The protocol also sought to induce A-Train to accept local and regional services. The consortium declared its willingness to do so but stressed its right to be "appropriately compensated”. At that time, representatives of regional transport authorities had also indicated their interest to start operations.

Six years after that the line was opened, a service between Uppsala and the airport (see Figure 1) is in operation while the airport is not used by Stockholm's commuter trains. There are some matching infrastructure investments that would have to precede commuter traffic and an obvious issue is who would have to foot the bill for that. But capacity is available on the tracks and since the types of services provided - the private operator's fast shuttle and the region's commuter trains with frequent stops - target different market segments A-Train would not be facing a direct threat against its core market. There is therefore an obvious scope for negotiations between the parties.

The poor year 2004 result indicated that A-Train defaulting on its loans was a real possibility. The private investor's share capital would then be foregone, the banks would sit with the highest-priority loans and the government's and the shareholder's loans have the lowest priority - but still higher priority than equity. The subsequent reconstruction,

\footnotetext{
${ }^{7}$ Ds 1995:33. Nya möjligheter för järnvägstrafiken. Fritzes, Stockholm.
} 
should it have happened, would probably have meant that some debt was written off and that some (private or public) operator took over management. The government could use its loan to provide some leverage in order to change operations in ways that would attract more usage. Importantly, bankruptcy would not mean any destruction of physical capital, only an adaptation to the reality of the situation, in particular to the below-target patronage. The 2005 and 2006 results have reduced the probability for default substantially.

As acknowledged by the enabling Act, the use of a private consortium to provide infrastructure and railway services has come at a cost. An overriding economic concern is the failure to attract coach travelers and car users to an environmentally preferable mode of transport. Furthermore, the airport authority has a problem with the environmental cap over Arlanda. In 2005, it therefore filed a request for having the cap removed since it would otherwise block further growth in air traffic from 2009. It is obvious that a commuter service would transfer passengers from busses and cars, therefore at least postponing the need to lift the cap.

\section{$4 \quad$ The search for an efficient industry structure}

Sweden's 1988 vertical separation of the railway sector split the state-owned operator into two parts: a public sector agency, responsible for the infrastructure and a state-owned monopoly operator. Freight services have subsequently been deregulated, the incumbent operator now has a monopoly franchise for "commercial” passenger services while "noncommercial" (that is, regional) services are procured on a lowest-subsidy basis. The bulk of subsidies today go into infrastructure (see Nilsson, 2002).

A core component also of the 1993 British reform was a vertical separation of the former British Rail. Passenger operators have competed for franchises and the bulk of subsidies are still channeled to operations (Nash, 2002). Following a recent EU directive, ${ }^{8}$ the rest of Europe has also made the vertical split, although links between the former infrastructure and operation divisions in several instances still are strong, thus reducing the scope for competitive entry.

The reforms should be seen against a background of European experiences of stateowned national monopolies, leaving a legacy of poor cost efficiency and inadequate services. The main motives behind the reforms have also been similar across Europe: To revitalize a sector that has had a persistently declining market share and recurrent financial problems that have required governments to prop up ailing operators. Sweden's reforms were also combined with an infrastructure investment program. A further purpose of the reform was to improve both allocative and cost efficiency in service operations, primarily by way of competition on or for the market.

There is, however, a growing concern that the vertical separation may have been ineffective. The OECD/ECMT Round Table has, for instance, recently warned that the European reformers may have been to fast to accept the separation of "natural monopoly" sections of the industry from the competitive segments (Kopp 2004). There may be a

\footnotetext{
${ }^{8}$ Directive 2001/14/EG. Directive of the European Parliament and of the Council of the allocation of railway infrastructure capacity and the levying of charges for the use of railway infrastructure and safety certification.
} 
severe risk for sub-optimization because of the vertical separation of responsibilities. Moreover, there are indications that competition for, or sometimes on the tracks, may enhance the industry's static efficiency (reduced costs for operating services) at the expense of service quality. These difficulties have not always been possible to overcome by contractual arrangements (Yvrande, 2000 and Yvrande-Billon and Menard 2005). Substantial transaction costs in the interaction between infrastructure provider and operators have also been a consequence of the vertical split.

In contrast, the US maintains a vertically integrated industrial structure. The freight business seems to be thriving, with services operated over long distances and carrying huge loads compared to the European context. A consolidation process seems to be going on in freight while some subsidized passenger services with poor profitability are operated over an infrastructure controlled by the freight operators. See Thompson (2006).

The Arlanda project points to the possibility to have vertically integrated firms operating their own regional or national infrastructure in parallel with one another. In this way, the economies of density in jointly operating infrastructure and services, lost in the vertically separated industry, can be retained. Moreover, new infrastructure can be designed according to the operator's demand. Would facility-based competition in parts of a vertically separated industry be beneficial for efficiency?

An obvious prerequisite for a policy to cut out slices of a national railway network and vertically (re-) integrate infrastructure and operations, would be that demand is high enough in order to pay for fixed costs of this segment. A second requirement is that demand is captive, that is, that customers have poor alternatives. If not, they would be deterred from using the service, severely limiting the efficiency in using existing resources. Third, the links between the facilities and the rest of the network should be small so that outsiders' access charges in excess of marginal costs would not distort resource allocation with respect to exchange with other parts of the network.

It is not obvious that the Arlanda link project is a good candidate for a public-private partnership: The costs were too high for the private consortium to foot the bill for it all, making it necessary for the government to provide a low-priority loan. Moreover, the alternatives to the railway services are highly competitive which means that it is difficult to recover costs with user revenue without scaring off demand. In addition, the charges levied for other railway services to get access to the airport station are high, adding to the below capacity use of the infrastructure.

However, there are also benefits of a deal of this nature. One is the oversight provided by both a diligent shareholder with money at risk and by commercial lenders to ascertain due diligence in the construction of the project and in the way it is being operated (Dewatripont and Legros, 2005). Bank consultants turn every stone to reduce lender risk in a way which is rare in the public sector where monitoring is often seen to be of secondary relevance.

An additional benefit is that taxpayers have not had to pay some SEK 1,7 billion for building the infrastructure. The economic benefit from this is that the dead-weight loss of raising the revenue by way of taxation way has never materialized. Although the Arlanda franchise has resulted in substantial efficiency losses, the alternative - that is, tax financing - would also have been distortive. From this second best perspective, there may be reason to implement even an efficiency distorting solution. We have also argued that a negotiated deal between A-Train, the operator of commuter services and the airport authority could 
improve the attraction of an environmentally attractive mode for travelers that today go by car.

It is always going to be difficult to organize competition in industries that have to rely on (monopoly) network facilities. The possibility to combine vertically integrated segments of the infrastructure with an otherwise separated industry should therefore not be dismissed. As competition developed in the telecommunications industry, the institutional and regulatory framework was successively reformed along lines that deviated substantially from the paths that were laid out by the initial reforms in 1984 in the U.K. (duopoly with restricted entry) and the U.S. (regional monopolies). The Arlanda link may provide an example of a path to take for gradual changes also in the railway industry.

\section{Conclusions}

Designing a contract for an infrastructure investment of Arlanda's type - that is, with a public sector principal hiring a private sector agent - opens up the standard issues of optimal contract design. Several of these issues were obviously dealt with in a conscious way in the Arlanda deal. One is that it is a life-cycle project, providing incentives for appropriate tradeoffs between spending on initial investment and future maintenance and operations. In combination with that the contract basically is of a fixed price nature, it provides proper incentives for cost efficiency and income generation. Moreover, the combination of equity and bank lending commits the consortium to the agreement.

The allocation of most risk to the concessionaire was premeditated. It is, however, not obvious that it is appropriate to leave all market risk to a private concessionaire, in particular in view of its poor ability to affect demand. On the other hand, the operator's (apparent) ability to bridge over the collapse of the market may indicate that it has succeeded in handling this task. The government's conditional loan is also designed in a clever way, both in that it reduces the debt burden during the first years of operations and in that it makes the government residual claimant for future profits should demand continue to grow. Taken together, the contract design is such that in case of default, the government does not have to chip in more money, except if it wants to organize operations in novel ways.

A further benefit of the deal is that taxpayers did not have to pay some SEK 1,7 billion for building the infrastructure. Even if there are distortions from providing a private contractor with certain monopoly rights, these negative consequences must be compared to the distortions coming with "ordinary" tax financing.

The prime problem with the concession is indeed that track capacity is not fully used at the same time at the alternative mode, roads, is over-used and has severe environmental consequences. The single most important indication of an economic problem is therefore the inability to dent road transport's market share. We have, however, argued that there are ways to negotiate a deal between A-Train and representatives for the airport and the region in order to handle at least some of these problems.

The Arlanda airport train shuttle illustrates the necessity of considering ex ante what could happen ex post and to design a contract with this in mind. In addition, the contract must be robust against events that are not anticipated at the contracting stage. In view of that both the Arlanda shuttle and most other Public-Private Partnerships have a very long 
duration, this incomplete contract feature is perhaps one of the most important things to keep in mind in order to make such deals beneficial for both parties.

The observations made in this paper point to important aspects of contractual design, including the allocation of risk, creating commitment and controlling for possible abuse of monopoly position. There is no way to generalize from this particular project to other potential PPP ventures. The paper has, however, pointed to the types of tradeoffs that must be scrutinized by an informed government in its dealing with profit maximizing private entrepreneurs. It also illustrates the problems with making ex post assessments of projects where relevant information is not readily available and where only a small part of the complete contract period has elapsed.

\section{$6 \quad$ References}

Andersson, N. (2005) "Improving Productivity for Nordic Public Infrastructure," Mimeo, Swedish Export Credit Association, available at www.sek.se

Dewatripont, M. \& P. Legros (2005) "Public-private Partnerships: Contract Design and Risk Transfer,” European Investment Bank, EIB Papers, 10:121-145.

Dixit, A. (1996) The Making of Economic Policy. A Transaction-Cost Politics Perspective. The MIT Press: Cambridge, Mass.

Enberg, N., L. Hultkrantz, J-E. Nilsson (2004) Arlandabanan. En uppföljning av samhällsekonomiska aspekter på en okonventionell projektfinansiering några år efter trafikstart. VTI notat 46-2004.

Flyvbjerg, B., N. Bruzelius, W. Rothengatter (2003) Megaprojects and Risk. An Anatomy of Ambition. Cambridge UP, Cambridge UK.

Kopp, A. (2004) The Limits of De-regulation of Transport Infrastructure Services. Report on the OECD/ECMT Round Table 129.

Laffont, J-J. \& J. Tirole (1993) A Theory of Incentives in Procurement and Regulation. The MIT Press: Cambridge, Mass.

Nash, C. (2002) "Regulatory Reform in Rail Transport - The UK Experience," Swedish Economic Policy Review, 9: pp. 257-286.

Nilsson, J-E. (2002) "Restructuring Sweden's Railways; The Unintentional Deregulation,” Swedish Economic Policy Review, 9: pp. 231-254.

Riksrevisionen (2004) Arlandabanan. Insyn i ett samfinansierat järnvägsprojekt. RIR 2004: 22.

Yvrande, A. (2000) "The New British Railways Structure: A Transaction Cost Economics Analysis,” Working Paper, ATOM, University of Paris. 
Yvrande-Billon, A. and Menard, C. (2005) "Institutional Constraints and Organizational Changes: The Case of the British Rail Reform," Journal of Economic Behavior and Organization, 56: 675-699. 